\title{
SISTEM INFORMASI BERBASIS WEB PANDUAN DIET BAGI PENDERITA PENYAKIT JANTUNG
}

\author{
Nur Heri Cahyana,Wilis Kaswidjanti, Anna Astrini Kartika Sari \\ Jurusan Teknik Informatika UPN "Veteran" Yogyakarta \\ Jl. Babarsari 2 Tambakbayan 55281 Telp (0274) 485323 \\ Email : dsnurheri@gmail.com
}

\begin{abstract}
The cause of heart disease is the result of a continuous process, in which the heart gradually loses its ability to perform functions normally and there was narrowing and blockage of heart arteries. The occurrence of blockage and narrowing of the coronary arteries is caused by the buildup of fatty substances (cholesterol, triglycerides) under the innermost layer (endothelium) of the artery wall. To prevent and reduce the risk of heart disease can be done by adjusting the diet according to nutritional needs, food is recommended and the type of heart disease suffered by the user. In this study using the method of Waterfall in perancanganan and development. This website is made by using the PHP web programming language and MySQL database, for layout and design using Macromedia Dreamweaver. Through this system, users can find a food that is recommended for the type of illness, and to know the nutritional calculation in accordance with the nutritional needs of the user to input some data users, then the user can select the desired food and knowing the energy content, protein, fat and carbohydrate in these foodstuffs.
\end{abstract}

Keywords : Dietary guidelines, Heart Disease, Web

Penyebab penyakit jantung adalah akibat proses berkelanjutan, di mana jantung secara berangsur kehilangan kemampuannya untuk melakukan fungsi secara normal dan terjadi penyempitan dan sumbatan dari pembuluh nadi jantung. Terjadinya penyumbatan dan penyempitan pembuluh arteri koroner tersebut disebabkan oleh penumpukan zat-zat lemak (kolesterol, trigliserida) di bawah lapisan terdalam (endotelium) dari dinding pembuluh nadi. Untuk menghambat dan mengurangi resiko dari penyakit jantung dapat dilakukan dengan cara mengatur pola makan sesuai dengan kebutuhan gizi, bahan makanan yang dianjurkan dan jenis penyakit jantung yang diderita oleh user. Pada penelitian ini menggunakan metode Waterfall dalam perancanganan dan pengembangannya. Website ini dibuat dengan menggunakan bahasa pemrograman web PHP dan database MySQL, untuk layout dan desain menggunakan Macromedia Dreamweaver. Melalui sistem ini, user dapat mengetahui bahan makanan yang dianjurkan untuk jenis penyakitnya, serta dapat mengetahui perhitungan gizi sesuai dengan kebutuhan gizi user dengan menginputkan beberapa data user, kemudian user dapat memilih bahan makanan yang diinginkan dan mengetahui kandungan energi, protein, lemak dan karbohidrat dalam bahan makanan tersebut.

Kata kunci : Panduan diet, Penyakit Jantung, Web

\section{PENDAHULUAN}

Penyebab penyakit jantung adalah akibat proses berkelanjutan, di mana jantung secara berangsur kehilangan kemampuannya untuk melakukan fungsi secara normal dan terjadi penyempitan dan sumbatan dari pembuluh nadi jantung. Terjadinya penyumbatan dan penyempitan pembuluh arteri koroner tersebut disebabkan oleh penumpukan zat-zat lemak (kolesterol, trigliserida) di bawah lapisan terdalam (endotelium) dari dinding pembuluh nadi. Salah satu faktor yang paling berpengaruh terhadap kemungkinan terjadinya penimbunan zat lemak ini adalah gaya hidup, khususnya pola makan. Penyakit jantung kerap diidentikkan dengan penyakit akibat "hidup enak", yaitu terlalu banyak mengkonsumsi makanan mengandung lemak dan kolesterol. Hal ini semakin menjadi dengan kian membudayanya konsumsi makan siap saji (junk food). Tidak dapat dihindari, junk food telah menjadi bagian dari gaya hidup sebagian masyarakat di Indonesia.

Meningkatnya jumlah junk food yang masuk ke pasar Indonesia pun memunculkan fenomena baru, yaitu obesitas atau berat badan berlebih. Masalah kegemukan ini juga makin 
banyak ditemui pada usia anak-anak dimana obesitas merupakan faktor resiko utamanya terjadinya penyakit jantung.

Sehingga seiring dengan berkembangnya teknologi komputer dewasa ini dimana teknologi komputer dapat dikatakan sebagai suatu kebutuhan dalam kehidupan sehari-hari. Teknologi komputer memberikan suatu sarana untuk menyajikan informasi secara cepat dan menarik. Teknologi komputer yang berkembang membuat informasi yang ada dapat didistribusikan secara luas dan kapan saja. Internet memegang peranan penting dalam pendistribusian informasi. Salah satu teknologi yang dapat digunakan pada jaringan internet adalah WWW (World Wide Web), orang biasanya mengenal dengan istilah website. Dengan menggunkan teknologi web, maka seseorang dapat mudah berkomunikasi dengan orang yang berjarak jauh dengan kita. Luasnya penggunaan internet telah membuka kesempatan bagi seseorang untuk dapat membantu mengatasi permasalahan yang dihadapi terutama dalam hal ini adalah Sistem Informasi Berbasis Web Panduan Diet Bagi Penderita Penyakit Jantung, dimana para pengguna khususnya bagi para penderita penyakit jantung dapat menentukan kandungan gizi, susunan menu, jenis makanan, dan jumlah makanan yang tepat dibutuhkan oleh tubuhnya dengan mudah.

\section{BAHAN DAN METODE}

\subsection{Sistem informasi}

Sistem merupakan jaringan dari elemen-elemen yang saling berhubungan, membentuk suatu kesatuan untuk melaksanakan suatu tujuan pokok dari sistem tersebut. Tujuan pokok dari sistem komputer adalah mengolah data untuk menghasilkan informasi. Sistem yang dimaksud di sini adalah sistem yang terotomatisasi, yang merupakan bagian dari sistem manusia dan berinteraksi atau dikontrol oleh satu atau lebih komputer sebagai bagian dari sistem yang digunakan (Hartono, 2003). Informasi adalah data yang digunakan dalam pengambilan keputusan, informasi dapat didefinisikan sebagai hasil dari pengolahan data dalam suatu bentuk yang lebih berguna dan lebih berarti bagi penerimanya yang menggambarkan suatu kejadian-kejadian (event) yang nyata (fact) yang digunakan untuk pengambilan keputusan (Hartono, 1999).

\section{2. Diet Pada Penyakit Jantung}

Diet adalah suatu aturan untuk mengatur pola makan dan frekuensi makan. Yang dimaksud pola makan adalah suatu susunan hidangan yang terdiri dari makanan pokok, lauk hewani, lauk nabati, sayur dan buah dalam sehari. Frekuensi makan adalah banyaknya asupan makanan per orang dalam sehari (Almatsier, 2005). Penyebab penyakit jantung adalah akibat proses berkelanjutan, di mana jantung secara berangsur kehilangan kemampuannya untuk melakukan fungsi secara normal dan terjadi penyempitan dan sumbatan dari pembuluh nadi jantung. Penyempitan disebabkan oleh penumpukan zat-zat lemak (lipid kolestrol) yang makin lama makin banyak langsung di bawah lapisan terdalam (endothelium) dari dinding pembuluh nadi. Pada awal penyakit, jantung mampu mengkompensasi ketidakefisiensian fungsinya dan mempertahankan sirkulasi darah normal melalui pembesaran dan peningkatan denyut nadi. Syarat-syarat diet penyakit jantung adalah (Almatsier, 2005)

1) Energi cukup, untuk mencapai dan mempertahankan berat badan normal.

2) Protein cukup yaitu $0,8 \mathrm{~g} / \mathrm{kg} \mathrm{BB}$.

3) Lemak sedang, yaitu $25-30 \%$ dari kebutuhan energi total, $10 \%$ berasal dari lemak jenih, dan $10-15 \%$ lemak tidak jenuh.

4) Kolesterol rendah.

5) Vitamin dam mineral cukup. Hindari penggunaan suplemen kalium, kalsium, dan magnesium jika tidak dibutuhkan.

6) Garam rendah, 2-3 g/hari, jika disertai hipertensi atau edema.

7) Makanan mudah cerna dan tidak menimbulkan gas.

8) Serat cukup untuk menghindari konstipasi.

9) Cairan cukup, \pm 2 litar/hari sesuai kebutuhan.

10)Bentuk makanan disesuaikan dengan keadaan penyakit, diberikan dalam porsi kecil.

11)Bila kebutuhan gizi tidak dapat dipenuhi melalui makanan dapat tambahkan makanan enternal, parenteral, atau suplemen gizi. 
Jenis Diet dan Indikasi Pemberian

1) Diet Jantung I

Diet Jantung I diberikan kepada pasien jantung akut atau gagal jantung seperti Myocard Infact (MCl). Dasar dari diet jantung I karena fungsi jantung terganggu maka aliran darah ginjal juga akan terganggu. Agar kadar ureum darah tidak meningkat maka perlu diberikan protein yang rendah. Kegagalan jantung bisa menyebabkan timbulnya oedema. Untuk mengurangi oedema, pemberian garam harus dibatasi.

2) Diet Jantung II

Diet diberikan sebagai perpindahan dari Diet Jantung I atau setelah fase akut dapat diatasi. Walaupun fungsi jantung terganggu, pengaruh terhadap fungsi ginjal belum tampak, sehingga dapat diberikan tinggi protein. Untuk mencegah terjadinya oedema perlu diberikan diet rendah garam.

3) Diet Jantung III

Diet diberikan sebagai perpindahan dari Diet Jantung II atau kepada pasien jantung dengan kondisi yang tidak terlalu berat. Bentuk makanan lunak atau biasa perlu diberikan makanan tinggi protein dan tinggi kalori.

4) Diet Jantung IV

Diet diberikan sebagai perpindahan dari Diet Jantung III atau kepada pasien jantung dengan kondisi yang ringan.

\subsection{Perancangan}

\subsubsection{Perancangan Proses}

Gambar . 1 menunjukan admin mempunyai kemampuan atau kewenangan untuk melakukan validasi data, sedangkan user hanya bisa memakai sistem ini dan tidak berwenang melakukan validasi data. User akan memasukkan data bagi sistem, kemudian sistem ini akan memberikan keluaran (output) pada user.

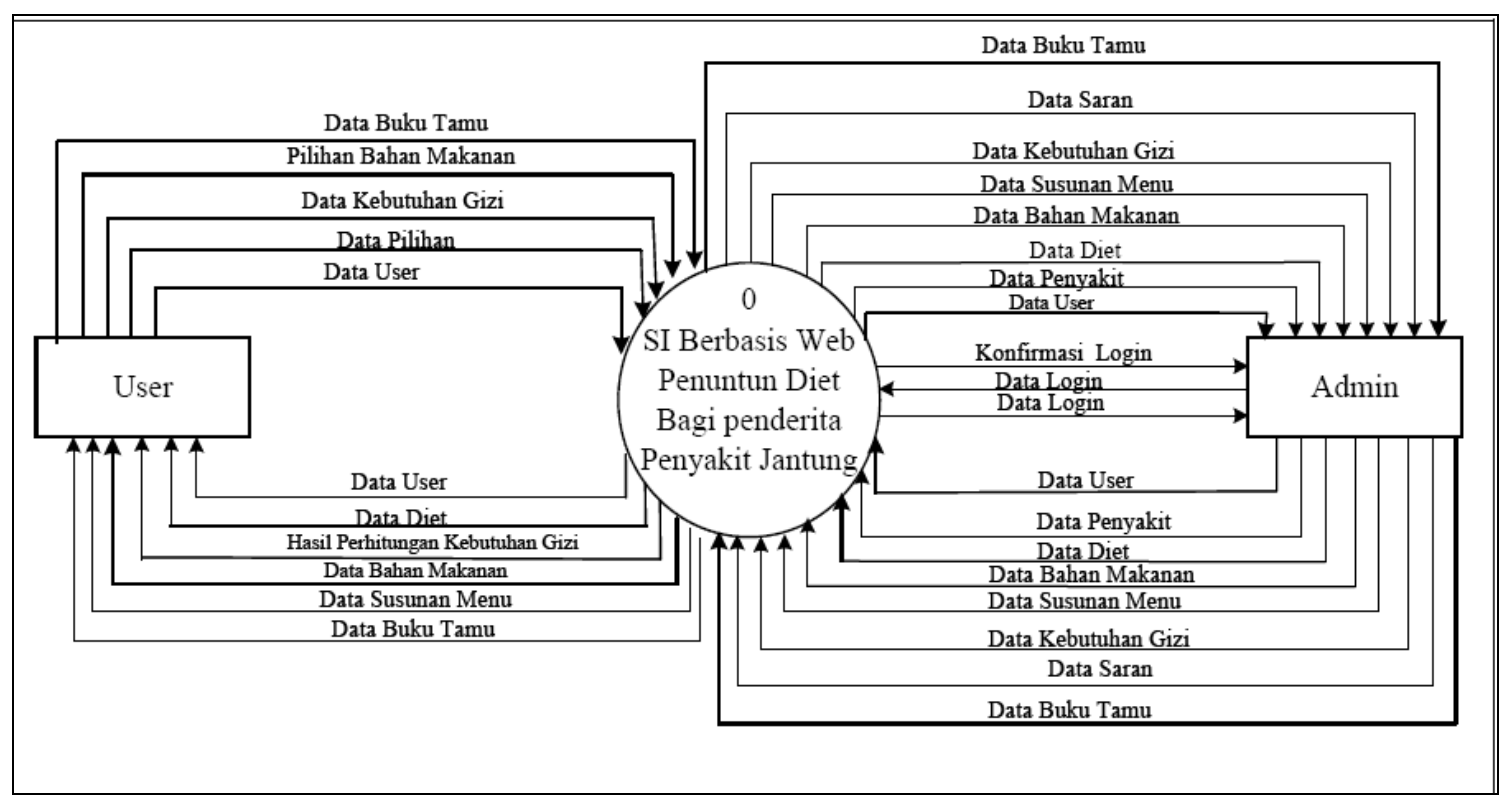

Gambar 1. Diagram sistem penuntun diet bagi penderita penyakit jantung 


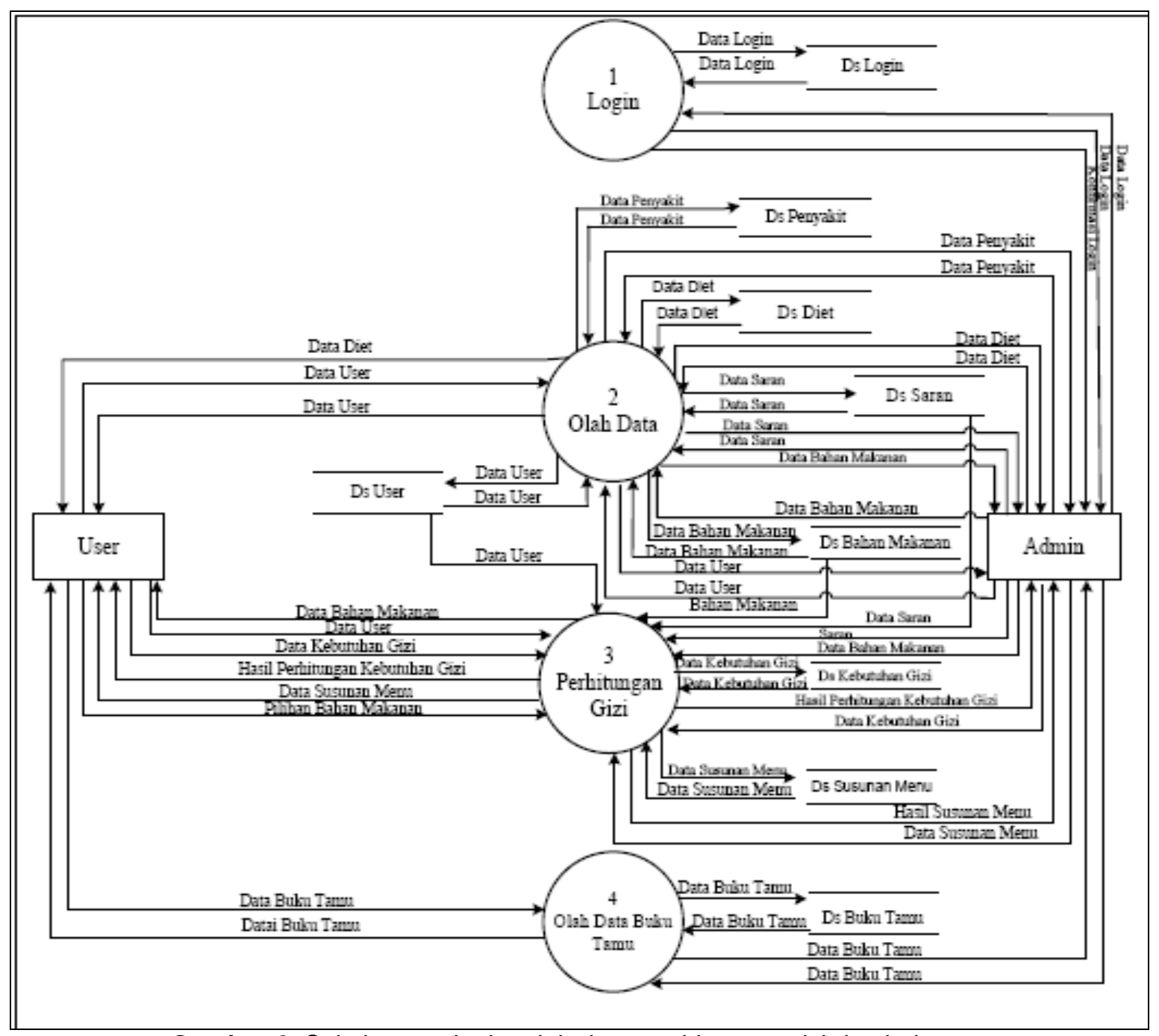

Gambar 2. Subsistem : login, olah data, perhitungan gizi dan buku tamu

Gambar 2. Merupakan diagram level 1 dimana masukkan dari user berupa data user data masukkan tersebut diproses lalu disimpan dalam datastore user keluarannya berupa data user. Selain data user kelurannya juga data diet yang dihasilkan dari datastore penyakit dan diet. Sedangkan masukkan dari admin berupa data user, data penyakit, data diet, data bahan makanan, data saran. Data masukkan tersebut diproses lalu disimpan dalam datastore user, penyakit, diet, bahan makanan dan saran. Keluarannya berupa data user, data penyakit, data diet, data bahan makanan, dan data saran. Proses ketiga adalah proses perhitungan gizi, masukkan dari user berupa data kebutuhan gizi dan data bahan makanan disini user memilih bahan makanan yang diinginkan data masukkan tersebut diproses dan disimpan dalam datastore kebutuhan gizi dan datastore susunan menu. Keluarannya berupa data kebutuhan gizi dan data susunan menu, data bahan makanan. Dan masukkan dari admin berupa data kebutuan gizi user, data bahan makanan, data saran dan data susunan menu. Data masukkan tersebut diproses lalu disimpan dalam datastore kebutuhan gizi user dan susunan makanan, didalam proses juga mengambil dari datastore user, bahan makanan, dan saran. Keluaran dari perhitungan gizi berupa hasil perhitungan kebutuhan gizi, data bahan makanan dan data susunan menu. Proses keempat adalah proses olah data buku tamu terdapat dua pengguna admin dan user. Masukkan data dari user adalah data buku tamu dan akan diproses dan disimpan dalam datastore buku tamu manghasilkan keluaran data buku tamu. Admin yang akan mengolah data buku tamu dan disimpan dalam datastore buku tamu menghasilkan keluaran data buku tamu.

Data user disimpan dalam datastore user, sedangkan untuk proses tampil informasi data diet diambil dari datastore diet dan penyakit. Keluaran bagi user berupa data user dan data informasi diet masukkannya berupa data user. Proses tersebut bisa dilihat pada gambar 3 


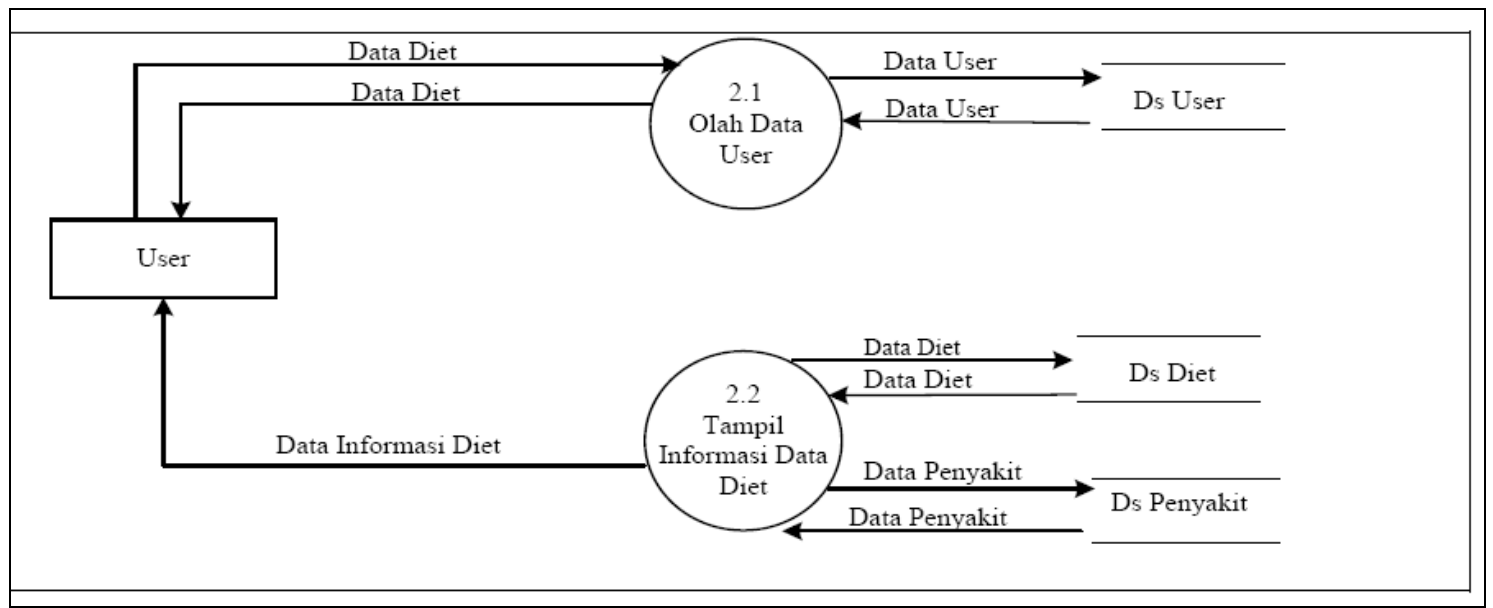

Gambar 3. Proses pada user

Proses perhitungan kebutuhan gizi user mengambil dari data yang disimpan dalam datastore user dan datastore kebutuhan gizi. Dan proses penyusunan menu diet sesuai kebutuhan gizi mengambil data dari datastore user, bahan makanan, saran dan susunan menu bisa dilihat pada gambar 4 .

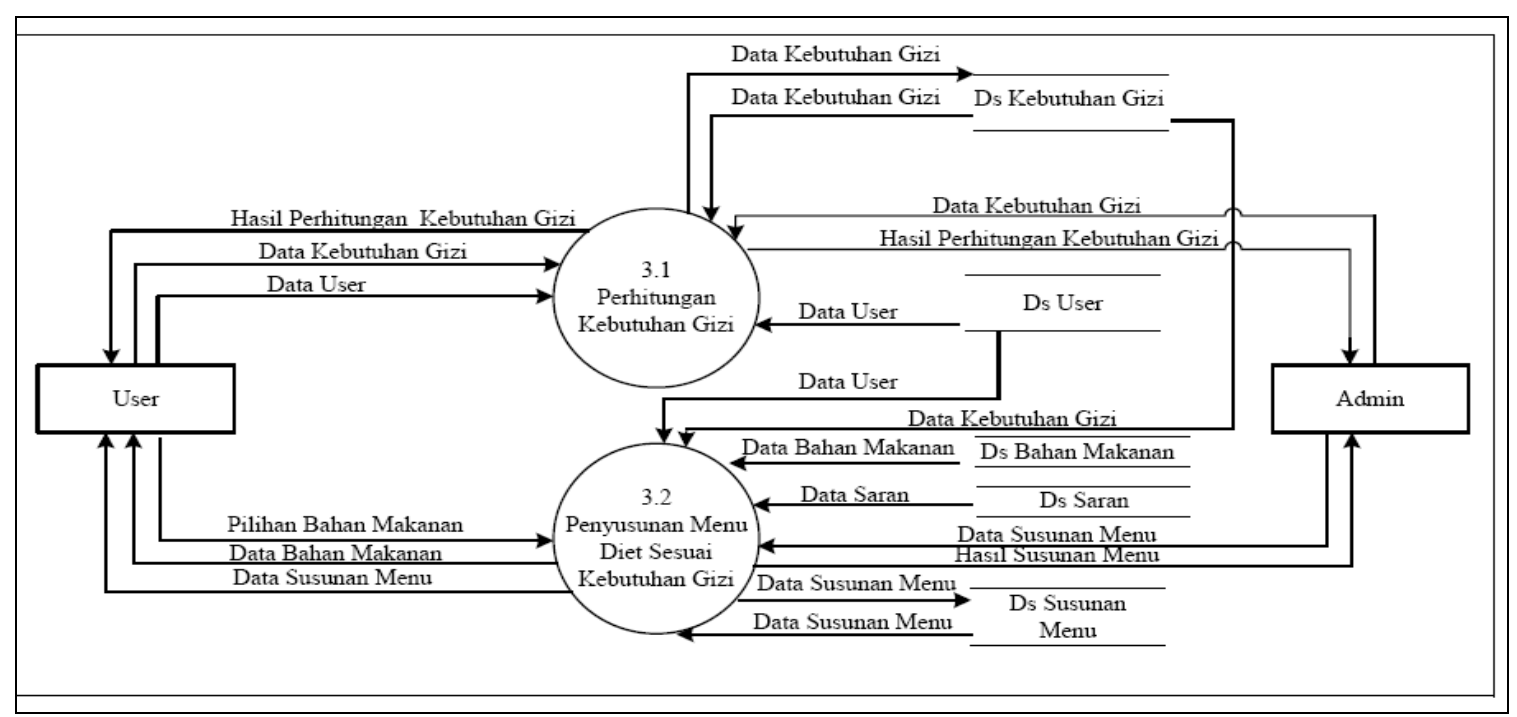

Gambar 4. aliran data perhitungan gizi dan penyusunan menu diet

Logika perhitungan kebutuhan gizi user dapat dilihat dengan struktur program flowchart (gambar 5). 


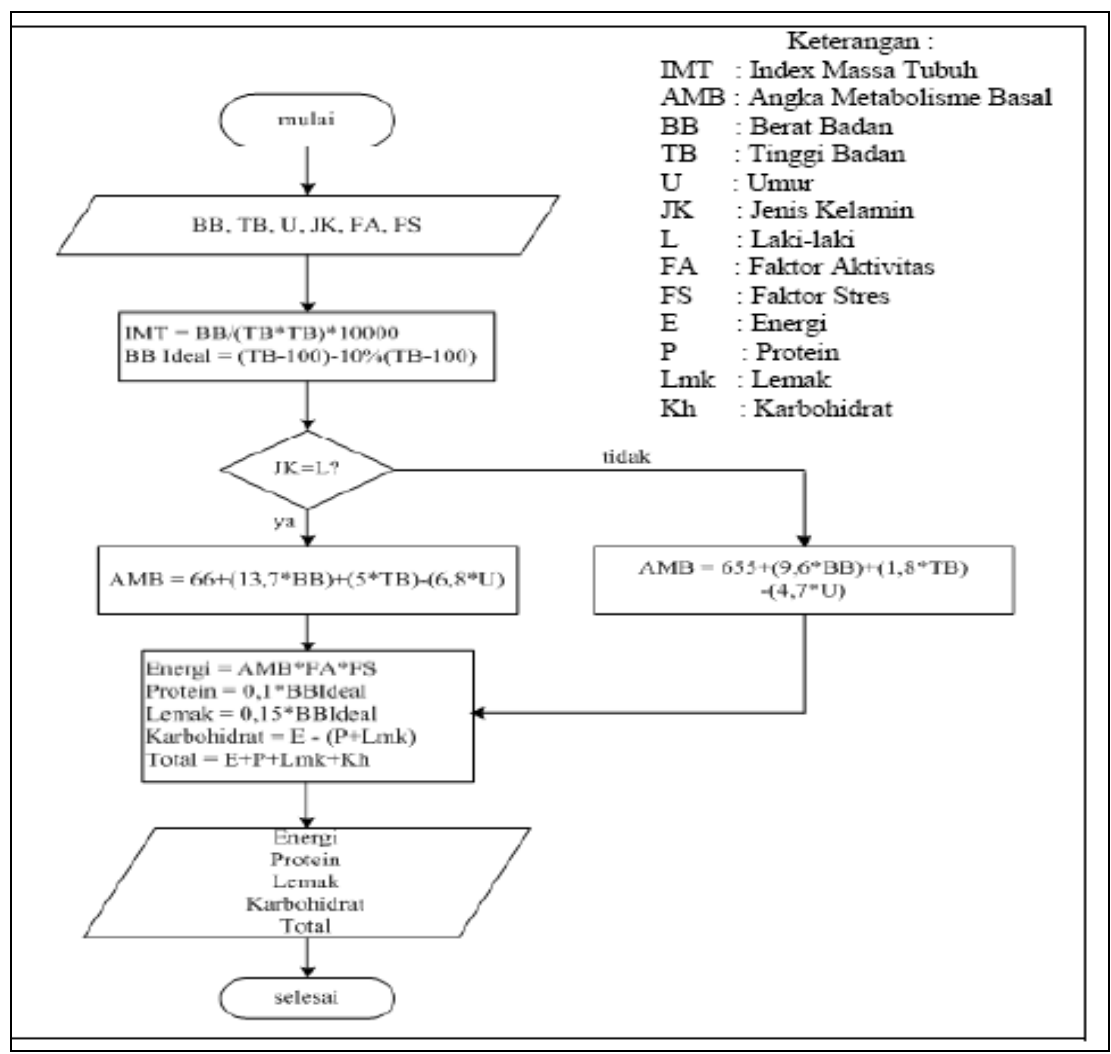

\subsubsection{Basis Data}

Gambar 5. Langkah Perhitungan gizi

Gambaran umum relasi atau hubungan antar tabel, dimana antar tabel yang saling berhubungan dapat saling berkomunikasi. Berikut ini dapat dilihat enttas relation diagram Sistem Informasi Berbasis Web Panduan Diet Bagi Penderita Penyakit Jantung pada gambar 6

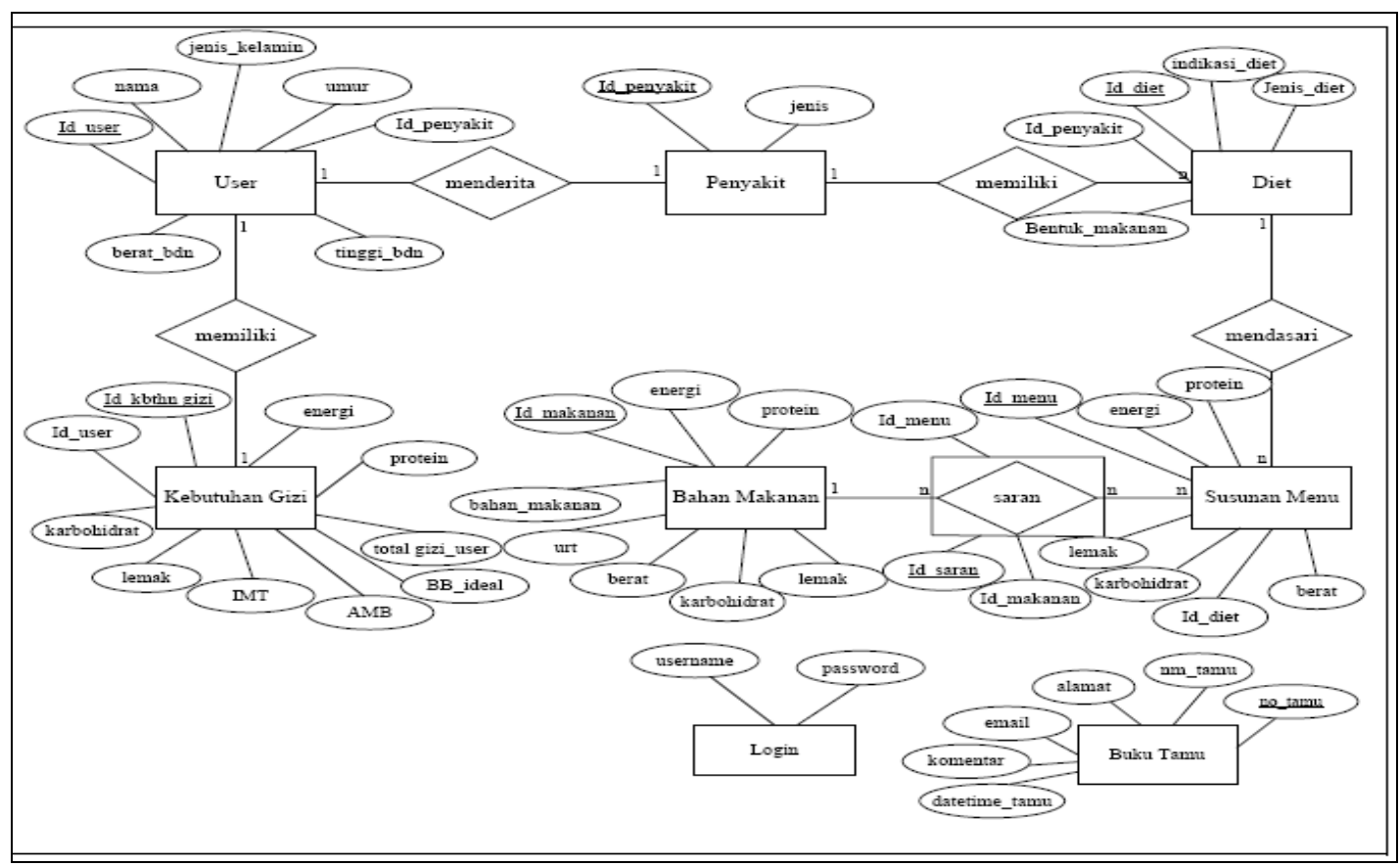

Gambar 6. ERD Sistem Panduan diet 


\section{IMPLEMENTASI DAN PEMBAHASAN}

Pada halaman ini berisi keterangan tentang diet penyakit jantung dan cara kerja sistem (gambar 7)

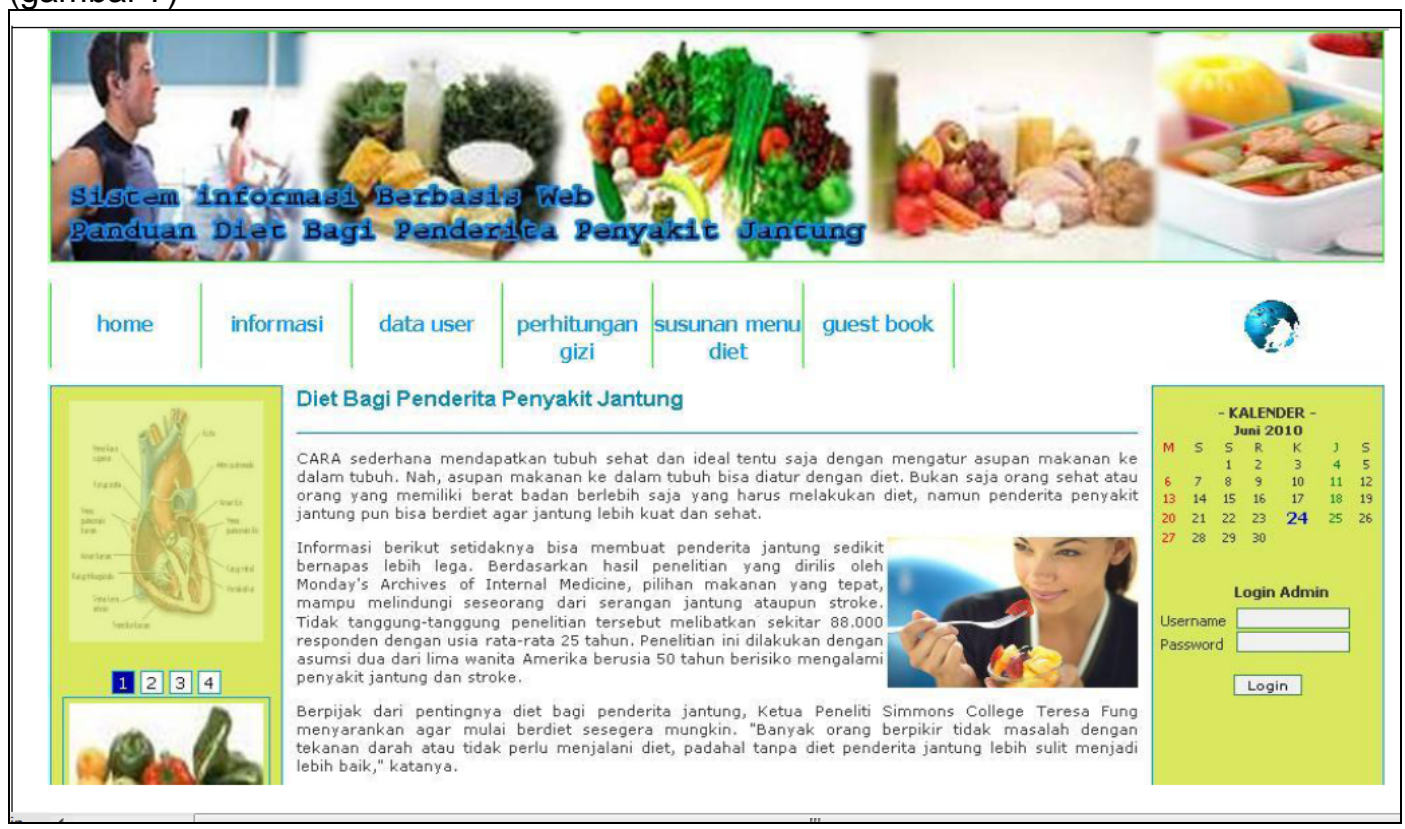

Gambar 7 halaman home

Halaman perhitungan gizi ini berisi tentang form perhitungan gizi dimana user hanya memasukkan id user yang diperoleh dari form data user. Sehingga dengan memasukkan id user, sistem ini akan menampilkan data yang dimasukkan user pada halaman data user secara otomatis. Kemudian user memilih faktor aktivitas dan faktor stress pada list yang telah disediakan. Tampilan halaman perhitungan gizi dapat dilihat pada gambar 8

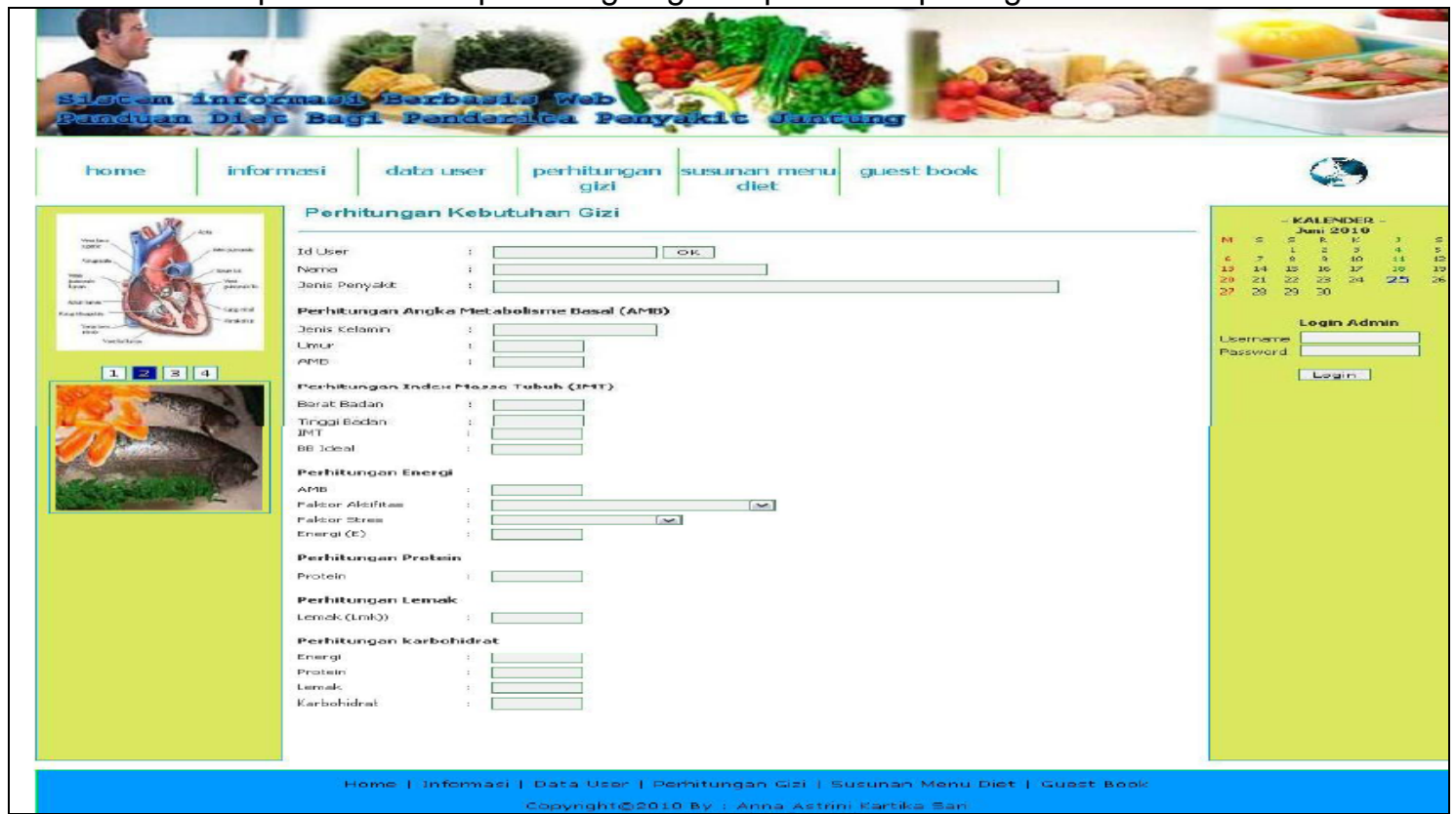

Gambar 8. Perhitungan kebutuhan gizi

Halaman susunan menu ini berisi tentang bahan makanan yang akan dipilih user sesuai dengan kebutuhan gizi dan susunan menu yang diinginkan dalam sehari, selain itu pada halaman ini terdapat perbandingan komposisi bahan makanan sesuai dengan energi, protein, lemak dan karbohidrat yang dipilih dengan kebutuhan gizi user (gambar 9). 


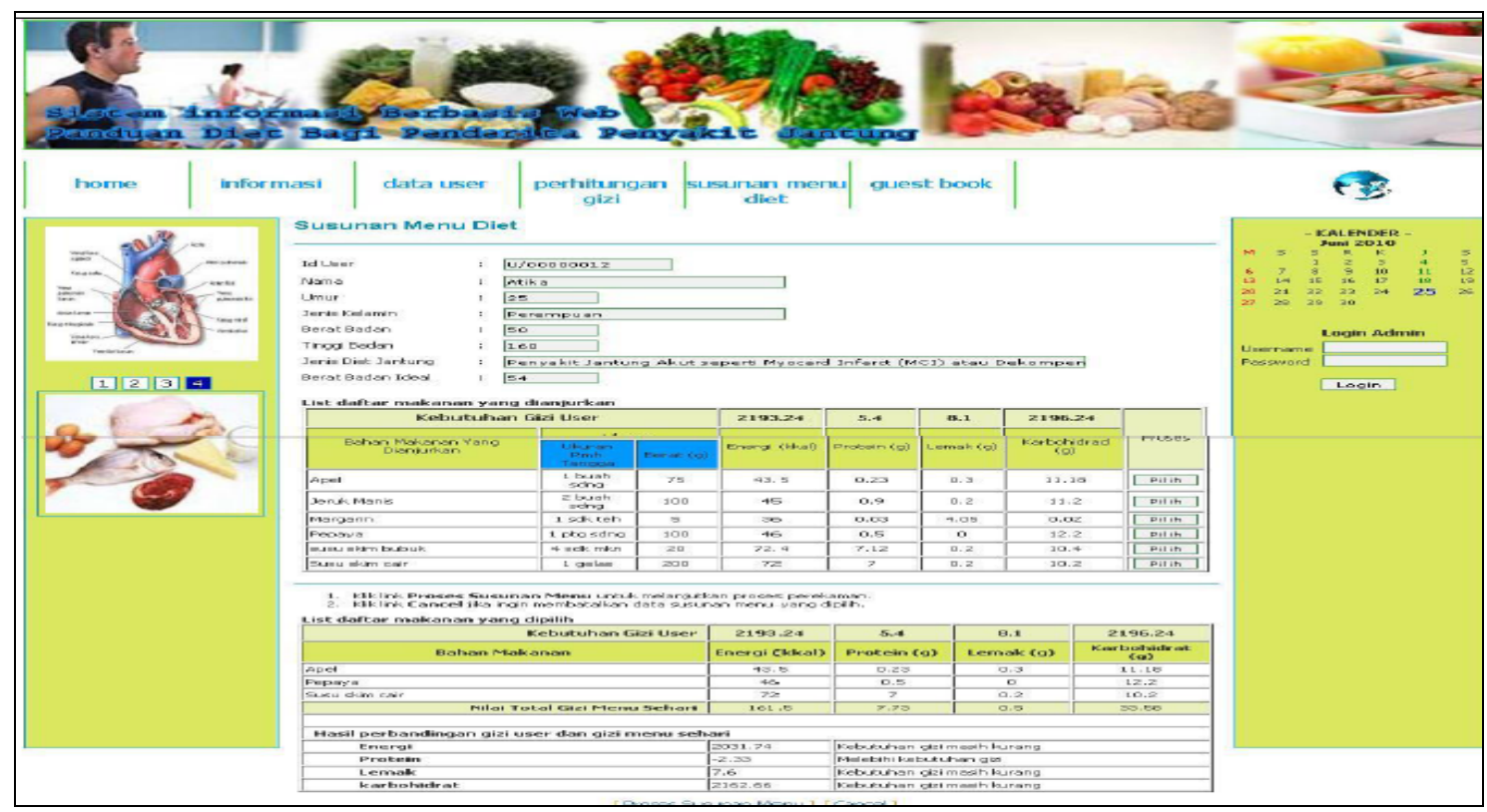

\section{KESIMPULAN}

Gambar 9. Susunan menu diet

Berdasarkan analisis, perancangan dan implementasi program, dapat disimpulkan bahwa dalam penelitian ini:

1) Telah dapat dibangun dan dihasilkan suatu sistem informasi berbasis web panduan diet bagi penderita penyakit jantung.

2) Sistem mampu memberikan perhitungan kebutuhan gizi kepada user berupa $A M B$ (Angka Metabolisme Basal), IMT (Index Masa Tubuh), BB ideal( berat badan ideal), serta dapat menentukan kandungan energi, protein, lemak dan kabohidrat yang dibutuhkan user sesuai dengan data pribadi dari user.

3) Sistem mampu memberikan saran susunan menu diet sesuai dengan pilihan user dan sesuai dengan kandungan gizi dan jenis penyakit jantung yang diderita.

4) Sistem mempunyai kemampuan untuk mengupdate, serta menghapus data diet dan bahan makanan yang dianjurkan oleh admin.

\section{DAFTAR PUSTAKA}

Atmatsier, Sunita, 2005, Penuntun Diet Edisi Baru, Gramedia Pustaka Utama, Jakarta.

Atmawikarta, Arum, 2001, Komposisi Zat Makanan Indonesia, Pusat Penelitian dan Pengembangan Gizi, Bogor.

Braverman, Eric R., 2006, Penyakit Jantung dan Penyembuhannya secara Alami, Bhuana IImu Populer, Jakarta.

Fathansyah, 2004, Basis Data, Cetakan kelima, Informatika, Bandung.

Hartono, Jogianto, 1999, Pengenalan Komputer, Andi, Yogyakarta.

Kadir, Abdul, 2002, Pengenalan Sistem Informasi, Andi, Jakarta.

Kadir, Abdul, 2003, Konsep dan Tuntunan Praktis Basis Data (edisi 2), Andi, Yogyakarta.

Kartasapoetra, 2008, IImu Gizi, Rineka Cipta, Jakarta.

Leod, Reymond, Sistem Informasi Manajement (edisi bahasa indonesia), Penhallindo, Jakarta.

Nugroho, Bunafit, 2004, PHP \& mySQL dengan editor Dreamweaver MX, Andi, Yogyakarta.

Nugroho, Bunafit, 2004, Aplikasi Pemrograman Web Dinamis dengan PHP dan MySQL, Gava Media, Yogyakarta.

Pressman, Roger, 2002, Rekayasa Perangkat Lunak Pendekatan Praktisi (Buku 1), Andi, Yogyakarta.

Sutarman, 2003, Membangun Aplikasi Web Dengan PHP dan MySQL, Graha IImu,

Yogyakarta. www.netcraft.com, (10 September 2009). 
